\title{
ISABELLA CORTESE - CZYLI ALCHEMIA URODY. KOBIECE PIĘKNO W TRAKTATACH WLOSKICH XVI W.
}

„Parmi ben che in lei [donna di palazzo] sia poi piú necessaria la bellezza che nel cortegiano, perché in vero molto manca a quella donna a cui manca la bellezza." [Jestem przekonany, że uroda bardziej jest potrzebna dworzance, niż dworzaninowi, albowiem wiele nie dostaje takiej kobiecie, której brakuje nadobności.] Tak napisał Baldassare Castiglione w traktacie Il Cortegiano ${ }^{1}$. Piękno zewnętrzne przedstawione jest tu nie tylko jako pożądany atrybut bywalczyni dworu, ale wręcz jako jej obowiązek. Wszystkie inne cnoty: szlachetność, odwaga, siła charakteru, wykształcenie czy rozwaga określane są jako ornamenti, podobnie jak suknie i klejnoty. Kobietę zdobią ponadto dobre maniery, umiar we wszystkim, skromność. Castiglione przyznaje, że kobiecie bardziej niż mężczyźnie przystoi dbać o urodę, lecz równocześnie napomina ją, że należy to robić w sposób nie nachalny i za nic nie można pozwolić innym poznać, jak wiele starań włożyła w dobranie stroju. Kobieta powinna też umieć rozpoznać swój typ urody i podporządkować mu sposób, w jaki będzie ukazywać się publicznie:

„Così, essendo un poco piú grassa o piú magra del ragionevole, o bianca o bruna, aiutarsi con gli abiti, ma dissimulatamente piú che sia possibile; e tenendosi delicata e polita, mostrar sempre di non mettervi studio o diligenzia alcuna." [Tak więc, każda dama, czy to nieco za gruba czy za chuda, niż przyjmuje się powszechnie za właściwe, blondynka, albo brunetka, może wspomagać swój wygląd, czyniąc to

1 B. Castiglione, Il Libro del Cortegiano, Gerolamo Cavalcaluolo, Venezia 1565, s. 268268. Jeśli nie zaznaczono inaczej, tłumaczenie polskie autorki artykułu. 
jednak w sposób jak najbardziej dyskretny, tak, aby, ukazując się na zewnątrz jako osoba pełna delikatności i poloru, sprawiała wrażenie, jakoby nie poświęcała zabiegom upiększającym najmniejszej uwagi ani zachodu. $]^{2}$.

Dyskurs normatywny każe tutaj kobiecie osiagnąć w dyskretny sposób wymierny efekt, nieledwie narzuca sprzeczne wymagania. Jakżeż bowiem osiagnaćc cel bez studio e diligenzia - uwagi i zachodu?

Podzielał pewno Castiglione opinię tych autorów, którzy za grzeszne uważali próby poprawiania własnej urody: „czy widział ktoś bowiem, aby poprawiać dzieła naszego mistrza Tycjana?", pyta w Istituzione delle donne współpracownik weneckich oficyn i autor oryginalnych traktatów na rozmaite tematy, Lodovico Dolce, porównując przy okazji pracę pędzla malarza, z którego Wenecja była dumna, do dzieła Boga - Stworzyciela ${ }^{3}$. Najwyraźniej jednak twarze czytelniczek Messer Lodovica bywały malowane. Pragnąc odwieść je od tego zgubnego zwyczaju autor, skądinąd propagator kształcenia dziewcząt i krytyk zbyt surowego ich traktowania, opowiada pewne wydarzenie, mające stanowić nauczkę dla stosujących makijaż kobiet: gdy podczas zabawy zaproponowano wszystkim zebranym damom przyłożenie do twarzy wilgotnego ręcznika, tylko te, których skóra nie była pokryta żadną substancja, trzymały w dłoniach czyste płótno... Dla zwiększenia wiarygodności kompromitująca w rezultacie propozycja „zabawy” wychodzi z ust młodej, nieumalowanej damy, która sama w niej naturalnie uczestniczy.

Do kogo pragnęły być podobne owe damy, uczestniczki niefortunnej zabawy? Czy nie do ariostowej Alciny: ,con bionda chioma lunga ed annodata”, o policzkach (dziś powiedzielibyśmy cerze) „misto color di rose e di ligustri” i oczach „sotto duo negri e sottilissimi archi/ son duo negri occhi, anzi duo chiari soli" Jak chce nasz thumacz Piotr Kochanowski „U długiej i na węzły powiązanej kosy/ Lśniały się, jako złoto, jej żółtawe włosy”, „Róże się, wychowane w sabejskich ogrodach,/Z fiołkami rozeszły po gładkich jagodach;/ Z gładzonych alaba-

\footnotetext{
Id., s. 275.Tłum. idem.

L. Dolce, Dialogo dell'istitutione delle donne, (Dialog o wychowaniu kobiet) Venezia, Giolito 1560, f. 26r-v.
} 
strów ma wyniosłe czoło”, i dalej: „Pode dwiema cienkiemi, czarnemi łukami/Są dwie oczy, ale je lepiej zwać gwiazdami"“? Taka wizja estetyczna podkreśla ,etyczne” przesłanki urody: jasne włosy i cera (ze śladami rumieńców będącymi oznaką zdrowia, ale także wstydliwości) - kojarzone są z bielą, symbolizująca, a więc i ukazująca, niewinność, dziewiczość, skromność.

Zapytajmy, czy istniały sposoby zbliżenia się do tego ideału, czy zostały one opisane, czy zachowały się do naszych czasów?

$\mathrm{Na}$ ślad naprowadził nas już Dolce, ze swoim czystym albo brudnym ręcznikiem. Na pytanie zaś, w jaki sposób czyniły to czytelniczki Ariosta, odpowiedzą nam traktaty i zbiory przepisów kosmetycznych, które w tym samym czasie opuszczały prasy weneckich drukarni. Znamy dzisiaj pół tuzina dzieł, które możemy nazwać „,kosmetologicznymi” i ok. 10 poświęconych wyłącznie destylacji zapachów i produkowaniu perfum. $Z$ pewnością musiały one cieszyć się popularnością, skoro były kilkakrotnie wznawiane.

Wszystkie powielaja schemat ricettario (receptariusza), nie przeznaczonego do lektury ciagłej, lecz konsultacji wybranych przepisów i sytuują się na granicy wiedzy z farmakologii, medycyny i alchemii, czerpią równie chętnie z wiedzy „wysokiej”, jak i ludowej. Taka formuła, nawet jeśli utwór pisany był językiem monotonnym i płaskim, gęsto usianym określeniami technicznymi, zapewniał mu sukces wydawniczy.

Są wśród tych wydań dzieła anonimowe, jak Le malicie de le Donne Narra(n)do tutti li lor belletti, \& acque stilate (...) che usano per farse belle (Sprytne wybiegi Kobiet. Opowiadajace o wszelkich kosmetykach $i$ pachnacych wodach, jakich używaja, by wydawać się urodziwymi) czy Opera nuova intitolata Dificio di Ricette...(Nowe dziełko zatytułowane Zbiór Przepisów...), wydawane dwunastokrotnie, począwszy od lat dwudziestych aż po lata czterdzieste XVI w ${ }^{5}$.

4 L. Ariosto, Orlando Furioso, canto VII, ed. Vincenzo Valgrisi, Venezia 1556, s. 62.Wyd. polskie, J. Czubek, Akademia Umiejętności, Kraków 1905, t. 1, s. 129.

Por. pod red. D. Menjot, Les soins de beauté. Moyen Age, Temps Modernes, Nice, 1985, P. Turrini, Bellezza di ieri...rivisitata oggi. Con un libretto di "segreti" di cosmetica del seicento, Università degli studi di Siena: scuola di specializzazione in scienza e tecnologia cosmetiche, Siena 6-7 luglio 2000. 
W tym samym czasie popularna była przeróbka dzieła wcześniejszego autorstwa lekarza i drzeworytnika Eustachio Celebrino Opera nuova piacevole la quale insegna di far varie compositioni odorifere... Intitulata Venusta. (Nowe przyjemne dzieło, które uczy jak sporzadzać rozmaite pachnidła, zatytułowane Venusta).

$\mathrm{Na}$ jego treść składa się ok. 100 różnorodnych przepisów z dziedziny kosmetologii, medycyny domowej, gospodarstwa domowego, higieny (np. walki z muchami, pchłami, wszami). Zatrzymajmy się tutaj jedynie przy przepisach kosmetologicznych, zajmujących większą część ricettaria. Znajdujemy tu kremy (ungento), podkłady pod makijaż, proszki do zębów, farby do włosów (pozwalające np. uzyskać modny wówczas we Włoszech kolor blond, ale też pokryć włosy siwe), produkty epilacyjne, do pokrywania plamek na skórze... Dużo uwagi poświęcono produkcji pachnideł: wód pachnących (rodzajów toników) stosowanych tam, gdzie my dzisiaj używamy kremów. Perfumowanymi wodami chętnie przemywano twarz, nasączano przedmioty, ubrania, pościel. Najczęściej stosowano olejek z migdałów słodkich i gorzkich, wodę różaną i lawendową, sok z cytryny i jabłek, a także kamforę, mączkę jęczmienną, liście pokrzywy...

Celebrino zaznaczał w pisanym oktawą wstępie, że nie potrafi, a może nie wolno mu przekazać całej posiadanej wiedzy:

Et perche son secreti assai diversi

Non posso dir vi il tutto in questi versi

[A ponieważ sq to sekrety tak bardzo różne,

Nie moge w tych wierszach wszystkiego zmieścićc $]^{6}$

Niepozorną książeczkę mającą to samo słowo secreti w tytule napisała kobieta - Isabella Cortese. Dziełko tej autorki, o której nie wiemy nawet, skąd pochodziła, zachwieje dychotomicznym obrazem piśmiennictwa dotyczącego kobiecej urody: Normatywna wizja estetyczno-etyczna w literaturze i traktatach, wyłącznie porady praktycz-

6 Za G. Corelli, Ricettario di bellezza di Eustachio Celebrino, (Receptariusz urody Eustachia Celebrino), Firenze, 1960, s. 137-150. 
ne w piśmiennictwie powstałym do powszechnego użytku codziennego ${ }^{7}$.

Sekrety czy może Tajemnice pani Izabeli Cortese, w których zawieraja się sprawy dotyczqce minerałów, medycyny, rzeczy wytworzonych [?] i Alchemii oraz wiele ze sztuki perfumeryjnej, przynaże każdej wielkiej damie, wraz z innymi najprzedniejszymi sekretami dołaczonymi pozostawały popularne zaskakująco długo, bowiem między pierwszym wydaniem w 1561, a ostatnim - (17. z kolei) w 1677 płynęło, co łatwo obliczyć, 116 lat $^{8}$. Żywotność tytułu wraz z zejściem z pras drukarskich nie wyczerpywała się ostatecznie i utwór nadal mógł przez jakiś czas pozostawać w obiegu czytelniczym. Dziełko nadal krążyło wśród licznych, średnio zamożnych, lecz stosunkowo „uczonych” czytelników. Mówi nam o tym z jednej strony mały format (wszystkie wydania ukazały się w in- $8^{\circ}$,) z drugiej - staranne opracowanie tekstu, zawierające także spis treści.

O popularności dzieła świadczy nie tylko wspomniane już 17 wydań weneckich, ale także dwa tłumaczenia na język niemiecki (wydane trzykrotnie, w Hamburgu w 1592 i 1596 i we Frankfurcie w tymże 1596 r.) oraz cytaty i odwołania rozsiane w siedemnastowiecznej literaturze alchemicznej, głównie francuskiej ${ }^{9}$. Od lat osiemdziesiątych XVII w. nie spotyka się już najmniejszego odwołania do utworu, a nazwisko autorki zapada w całkowitą niepamięć.

To, co wydawać nam się mogło zbiorkiem praktycznych porad, okazuje się owocem, o czym sama autorka pisze w liście dedykacyjnym do archidiakona Ragusy (dzisiaj: Dubrownika), wieloletniej pracy i „wyrywania” naturze mądrości. Przekonana o potrzebie docierania do tajemnic natury wpisuje się Cortese w dyskusje na temat natury

7 Wiadomości o Isabeli Cortese czerpiemy głownie z M. Marra, Introduzione Ai Secreti di Isabella Cortese, www.levity.com/alchemy/isabella.html.Wg P. Burke, La Renaissance en Italie : art, culture, société, Paris, 1991, spod piór kobiecych wyszło 158 utworów literackich i 38 określanych jako „naukowe”. Stanowi to najwyżej kilka procent „produkcji” wydawniczej, którą najnowsze obliczenia szacują na ok. 6000 wydań w I poł. stulecia i 7420 w II., z czego 556 stanowiły wydania dzieł powstałych współcześnie.

8 I. Cortese, Secreti..., Venezia, Giovanni Bariletto 1561 i Venezia, Antonio Tivanni, Venezia, 1677. Szerzej pisze na ten temat E. Bartochowska, Ksiega czarownicy, czyli kilka uwag o „I Secreti de la Signora Isabella Cortese”, Roczniki Biblioteczne, 2007. r. 51, s. 127-144.

9 Por. M. Marra, op. cit. 
ducha i harmonii między ciałem a duszą. Zwraca uwagę na znaczenie osobistego poznania natury metali, konieczność zachowania tajemnego charakteru wiedzy i jej łączność z modlitwą - pochwała Boga i jałmużna powinny nieodłącznie następować po seansie w laboratorium... We wstępie do księgi drugiej autorka zamieszcza zbiór porad, ujęty w formę dekalogu, przeznaczonych dla każdego, kto chce wejść do świata trudnej sztuki alchemii. Isabella polemizuje równocześnie z filozofami (Rajmondem Lullo czy Arnoldem da Villanova) jak równy z równym, czuje się ich partnerką - a tematy dotyczące kobiecej urody i pracy nad jej ulepszaniem stają się tym samym godne poważnego dyskursu. Historycy alchemii twierdza, że opisywane przez Izabelę procedury świadczą o jej dużej wiedzy w tej dziedzinie i o tym, że osobiście przeprowadzała eksperymenty.

Przypomnijmy, że alchemia nie jest ani magia, ani przodkinią chemii. Nie wolno postrzegać jej, uciekając się do nowoczesnych kryteriów nauki eksperymentalnej. Alchemia poszukuje absolutu, rozumianego jako jedność tego, co materialne i duchowe, a swoje badania opiera na zasadzie analogii i wierze w duchowy charakter materii. Całość Stworzenia: ludzie, planety, kamienie, rośliny, zwierzęta, nosi w sobie „pierwszą przyczynę życia”. Cały wszechświat jest zasadniczo jednością, a „stężenie” Ducha warunkuje formę materii - w kamieniu jest go mniej niż w człowieku... Każda cząstka duchowa posiadała moc stwarzania, a celem alchemika było właśnie powtórzyć ten proces, w skali mikrokosmosu. Należało wydestylować ów „pierwiastek stwórczy" - Ducha - z materii, oraz wejść w posiadanie substancji na tyle czystej, by była ona w stanie całkowicie „nasiąknąć” duchem i stać się w ten sposób jego konkretyzacją. Zamiana żelaza w złoto czy wody w eliksir młodości nie była zatem celem samym w sobie, lecz dowodem na posiadanie zmaterializowanego Ducha. Teraz możliwe staje się powtórzenie procesu stwarzania - również poprzez tworzenie Piękna. Isabella Cortese, pisząc o miksturach służących kobiecej urodzie (wybieleniu skóry czy zębów, farbowania włosów, zawsze przestrzegała 4 faz eksperymentu alchemicznego: dekompozycji, oczyszczenia, redukcji i utrwalenia. Oczyszcza najczęściej na słońcu, redukuje za pomocą wyciskania bądź destyla- 
cji, następnie studzi albo ponownie wystawia na słońce (konserwuje), ogromną wagę przywiązuje też do rodzaju pojemnika, w jakim substancja będzie przechowywana i do jego szczelnego zamknięcia... Upiększanie jest możliwe poprzez „oczyszczanie krwi i złych humorów i osuszanie słonej flegmy", a więc przywracanie równowagi.

Czy uważna lektura pokazałaby tylko, że niektóre przepisy są nie do powtórzenia (mamy współcześnie kłopoty z odczytaniem wszystkich podawanych przez autorkę wag), a inne $-\mathrm{z}$ powodzeniem moga być wykorzystane - o ile nie zniechęci nas długa i uciążliwa procedura produkcji mydła różanego czy wywabiacza tłustych plam? Czy zainteresowanie dziełkiem Isabeli Cortese jest jedynie odkurzaniem zabawnej skądinąd ciekawostki wydawniczej, czy może też szansą na uchwycenie ważnego ogniwa między filozoficzną i literacką wizją piękna, a praktycznym jego wspomaganiem? Ogniwa świadczaceego także o większej, niż zwykliśmy sądzić, jedności ówczesnego świata. 